\title{
LOS RECORRIDOS DE LA CIUDAD Y DE LAS PALABRAS: LECTURAS DE LA EXPERIENCIA EN PERIFÉRICA BLVD ${ }^{1}$
}

\author{
TRAVELINGS OF CITY AND WORDS: READINGS OF \\ EXPERIENCE IN PERIFÉRICA BLVD
}

Florencia Rossi ${ }^{2}$

Una de las formas de hablar de la ciudad, y sobre la ciudad, es a partir de quienes la caminan, la habitan a diario. También, de quienes escriben sobre y en ella, quienes la marcan, porque cada movimiento que hacemos, tiene una consecuencia, una huella de lo que fue y no es más. También, podemos pensar a la escritura como un hacer más cotidiano, como el caminar (DE CERTEAU, 2000), y en tanto praxis, deviene también de ese habitar la ciudad, de la experiencia misma de su tránsito. Sin embargo, algunos textos potencializan y encarnan esa experiencia de la ciudad en la escritura. De esta forma, lo que leemos no es la ciudad como fondo, sino como tras-fondo tejido a partir de la relación piso-pies como metáfora de la experiencia de la territorialidad.

Esta forma de comprender la relación entre el suelo y quien la pisa, como vivencia, proviene de Eduardo Lalo, artista puertorriqueño con el que trabajé en mi trabajo final de licenciatura (ROSSI, 2014), quien propone en un pequeño manifiesto tres posibles relaciones móviles que se pueden articular: filosofía y geografía, filosofía y autobiografía y filosofía y documento (LALO, 2005). Alguien expresa, alguien experimenta.Así, pensamos a la territorialidad como convergencia y superposición de planos que se arraigan en unos pies que sostienen el cuerpo en ese mismo

1 Texto base de ponencia apresentada durante as XII Jornadas Andinas de Literatura Latinoamericana - JALLA, La Paz, em agosto de 2016.

2 Universidad Nacional de Córdoba, Grupo de estudios sobre narrativa boliviana. 
"espacio" que configuran. La ciudad, protagonista en ambos autores con los que trabajaré Eduardo Lalo y Adolfo Cárdenas, simplemente porque es su donde, se compone entonces de diferentes historias, texturas, escrituras e imágenes.

En esta ocasión, les propongo transitar La Paz a través de Periférica Blvd (2013) de Adolfo Cárdenas. Periférica es una obra que se ha trabajado desde el barroco y el lenguaje. Sin embargo, lo que más recuerdo en sí después de haber leído - escuchado - este libro, es una sensación. Esa sensación hizo que imágenes quedaran impregnadas y otras olvidadas, pero que los murmullos fueran la guía para la misma. Es obvia la sonoridad, sólo pensarla en un ópera rock-ocó, pero a partir de esa sonoridad “de las palabras”, podemos leer la sonoridad de La Paz. Sí, leemos el sonido. Y, mientras, transitamos- caminamosuna ciudad.

¿Qué pisamos cuando pisamos? ¿Cómo lo hacemos? William Camacho propone la idea de "urbandino" (2009) para hacer referencia a esto, a la experiencia abigarrada "múltiple" un poco como una forma de juego teórica, otro poco como categoría como forma de vivir en una ciudad atravesada por diversas capas temporales y espaciales.

$\mathrm{Y}$ esto porque, como dije en otro momento, una ciudad se compone de instantáneas superpuestas, texturas, historias y voces de quienes la habitan. Al textualizarse, volverse texto (DE CERTEAU, 2000), deviene una ciudad escrita - ciudad ficcional - a la vez que un lugar epistemológico, con una forma de conocimiento diferido y particularizado. Su ficcionalización ha ido cambiando en distintas épocas, recordándonos siempre que es un espacio de tensiones que se actualizan a diario, en cada calle y desde cada calle caminada. O, mejor aún, en tanto "abigarrada" (como postula Zavaleta Mercado), convergen múltiples líneas, forman un tejido de relieves y materialidades diversas. A su vez, la experiencia del recorrido de la ciudad lleva a pensar(nos) cómo influye lo que pisamos, cómo escribimos y desde dónde.

Eso es lo que veo en Periférica desde el trabajo con el lenguaje. Cada personaje habla diferente porque son construcciones de territorios diferentes. Sin perder de vista el artificio barroco que utiliza Cárdenas, pueden ser cartografías de la ciudad a partir de estos lenguajes. Pero, 
más allá de eso, para mí, es un libro del rescate de la experiencia del atravesamiento de un espacio que se crea a partir de la acción misma de atravesarlo "poéticamente". Se textualiza, se territorializa, a partir de imágenes móviles que denotan un punto en el espacio, un foco. Yo, como lectora de ese foco, me veo inmersa. Por un lado, sí, leo el artificio, la genialidad de Cárdenas. Pero por el otro, hay algo que trasciende, que es el tejido invisible que une las letras y las palabras, eso es la experiencia de lectura y de apropiación del libro. 'Desaparece el libro en sí (cerrado) para ser el libro a partir de su transición- lectura, como Lalo plantea (2005).

Todo está territorializado (DELEUZE; GUATTARI, 2004). Sueño territorializado, lenguaje territorializado, música territorilizada. Como parte del mismo devenir territorio escrito, todo está grafiteado. Está todo marcado por un donde del cual es imposible escapar (LALO, 2003). Este es el concepto que utiliza Lalo y que me interesa rescatar como metáfora -idea (DELEUZE, 1996) que puede ir cambiando, pero que está arraigada en la experiencia del cuerpo: "un "espacio" determinado por puntos de la geografía y de la mente, construido por la acción de la cultura y la inconsciencia de la gente" (LALO, 2005, p. 25). Periférica, desde esta idea, es una vuelta a la materialización, no porque aparezcan objetos y espacios "concretos" (tanto como la Huari), sino por la vivencia-experiencia sumamente poética y creativa de lo cotidiano (y a la vez particularizado) de caminar, en este caso, a 3600 metros.

El trazado de mapas - de la ciudad, de la caminata, de lectura o de escritura - es la forma de teorizar desde ese modelo rizomático desde las líneas, a su vez, territorializadas (DELEUZE; GUATTARI, 2004). En Micropolítica. Cartografía del deseo (2013), Félix Guattari y Suely Rolnik resignifican a la cartografía como método y como recorrido de lectura de las imágenes-conceptos, como el de territorialidad. Además, sistematizan la noción de territorio desde un vínculo con la subjetivación, giro necesario para pensar tanto en la poética laliana como en el libro de Cárdenas: "El territorio puede ser relativo a un espacio vivido, así como a un sistema percibido en cuyo seno un sujeto se siente "en su casa". El territorio es sinónimo de apropiación, de subjetivación encerrada en sí misma (GUATTARI; ROLNIK, 2013, p. 466). 
El territorio es el espacio vivido y percibido por lo que, necesariamente, tiene que pasar a través de alguien que lo perciba, que viva en él, que lo habite. Un Severo, un Cárdenas, nosotros los lectores. Así, atravesamos la ciudad y la novela. De esta forma, el libro se vuelve un espacio practicado (DE CERTEAU, 2000, p. 128). Si "hay territorio desde el momento en que hay expresividad del ritmo" (DELEUZE; GUATTARI, 2004, p. 321), el libro mismo podría ser pensado como territorio a partir de la idea de la marca. Es decir, el ritmo no solo como sonido sino también como trazo. Justamente, porque expresa el ritmo de la escritura que, a su vez, "no tiene que ver con significar, sino con deslindar, cartografiar” (DELEUZE; GUATTARI, 2004, p. 11). De esta forma, el libro ha devenido una superficie marcada y marcable en la que se puede rastrear un mapa de expresividad. Mientras haya expresión, habrá territorialización. ¿Y qué es la ópera rock-ocó sino expresiones musicales y trazos? ¿Grafities en la ciudad y en el papel?

Tanto Cárdenas como Lalo producen desde una "escritura rayada", lógica "de los pueblos que han formado la periferia de occidente" (LALO, 2005, p. 131) que, si bien negada, existe. Estas son rayas que marcan y trazan, que se acumulan y manchan las paredes y el papel y que las convierten, como Barthes (2002) diría, en superficies marcables. Por separado, no dejan de ser líneas delgadas. Juntas, encarnan la experiencia de espacio superpuesto con impresiones acumuladas.

Para Lalo, la creación estética parte del recorrido de la ciudad, de una manera cotidiana: se escribe con los pies sobre San Juan (incluso, pisando la rue de París). Su poética emerge de la experiencia de la territorialidad misma, del recorrido, de la mirada de los pies sobre el suelo. Justamente, el suelo no es una cuestión meno, tampoco para Cárdenas. Tanto en los textos de Lalo, como en Periférica (recordemos el barro), el peso del suelo está remarcado. Hay una sensibilidad: la del donde que viene del mirar(se) los pies. Periférica es una novela del movimiento; del movimiento por la ciudad, por La Paz, por sus paredes y del movimiento elíptico del alejamiento y acercamiento. Es una novela de alturas, y basta recordar el 
capítulo "Vuelo rasante Vuelo rasante Vuelo rasante"3 o las elevaciones soñolientas (2013, p. 124).

Mediante la expresividad que conlleva todo proceso de territorialización, llegamos a la textualización de la misma. Esto porque el libro se ha vuelto, desde una lectura deleuzeana (2004), un territorio en sí mismo, a la vez que una herramienta que territorializa desde la escritura. A partir del ritmos se territotializa la ciudad de La Paz. ¿Y qué escuchamos en las lenguas sino ritmos?

En conciliación con lo que Cusicanqui (2010) plantea, entiendo que la operación de Cárdenas es doblemente des-esencializadora: por un lado, de "una" La Paz y, por el otro, de "una" forma de apropiación y uso de la lengua allí. Todos los capítulos son bien diferentes; como lectores, cuando llegamos a introducirnos en una atmósfera, una lengua, dura lo que dura ese capítulo. Cárdenas lo cambia todo porque no hay una sola periferia, ni una sola forma de habitarla. Tampoco hay un solo narrador ni enfoque para hablar de la misma. El primer capítulo, "Un chojcho con audio de rock pesado", es una muestra del manejo de los distintos registros (incluso verbal o no verbal), y de la consciencia de sus diferencias (como en el caso del locutor o del Teniente Villalobos). Este es uno de los capítulos ${ }^{4}$ en los que se puede ver esa oralidad en la escritura; oralidad que nos obliga a hacer una lectura "fonética" en voz alta, a escuchar esos sonidos a través de nuestra propia forma de decirlos-emitirlos:

Ya deja de lloriquear, mariconsito y canta: Este que está papando moscas es tu cuate? (...) mi tenienteeeee! Llamando hasta que lubrico cerca de la salida (...) el jefe lesta preguntando preguntando: cuáles mostrámelos y el llockallaauqellos que están allá: los Desput's dice el chif (...) Oquendo lostá llamando mi teniente; dile que voy aurita y vos no has visto ni oído nada, entendido? - Entendido mi teniente le digo aunque todavía no entienda ni nalgas no? (CÁRDENAS, 2013, p. 11).

Esto hace que sea un libro, al menos desde mi experiencia, de una lectura lenta. Sin embargo, como todo en este libro, los ritmos cambian. En cada capítulo, encontramos un registro de una experiencia diferente

3 Este capítulo puede trabajarse a partir de la idea del barroco, ya que abundan elementos del mismo.

4 Hay que recordar que primero fue un cuento que dio origen, luego, a la novela. 
de la ciudad, un sonido diferente, con palabras más o menos familiares. Lo constante, eso sí, es un murmullo que nos marca un ritmo, nos hace avanzar y caminar por el libro-ciudad.

Esta novela se vuelve una exposición de distintas voces identificables como partes de un tejido musical, incluso sectorizadas geográficamente por barrios, que van marcando las subjetividades (travesti, policía, alguien del alto, de Villa Fátima, etc). Como ya expresé anteriormente, la gran apuesta por esta representación de sonidos es que, si bien todos constituyen el ruido periférico de La Paz, pueden identificarse por separado. Es la proliferación de los significantes, de las diferencias, y el avanzar por el recorrido de las distintas periferias. Además, hay una gran consciencia de las diferencias de registros, como el paso de lo oral a lo escrito, resaltado por los dibujos de notas o listas que va haciendo el teniente, o la consciencia del locutor de radio. Justamente, la experiencia del atravesamiento se pretende total. A su vez, sería posible hacer una suerte de cartografía de los barrios paceños y sus alrededores de acuerdo a su forma de hablar y a la música que se escucha: en El Alto el rock y en Villa Fátima la música tropical, por ejemplo.

La imagen en sí de lo travestido, el juego entre lo que es y no es (condensado en las máscaras y la pintura) forma parte también de la potencia de lo indiferenciado, o en este caso, el audio de lo indiferenciado. En estos días de las JALLA, Cusicanqui nos habló del don de la palabra diversa, como esta "teje con el paisaje y la habitación humana". El gran trabajo respecto a lo auditivo es una técnica estética, pero también una epistemología desde una experiencia de un espacio. Ante el silencio. Cárdenas ensordece con un lenguaje artificioso y "travestido". ${ }^{5}$

Cárdenas escribe una acumulación sonora, una ópera de barro, el devenir del murmullo. Es más bien ese grano de la voz al que se refería Barthes que "no es indecible (...). Se puede por lo tanto describir el grano de una voz, pero solamente a través de metáforas” (BARTHES, 2013, p. 160) o, en este caso, por la acumulación sonora del murmullo. De esta

5 Sarduy se refiere a la carnavalización como otra de las características barrocas en tanto "equivale a confusión y afrontamiento, a intersección de distintos estratos, de distintas textualidades lingüísticas, a intertextualidades" (Sarduy, 2011: 20). En Periférica Blvd podemos ver a la parodia en los nombres de lugares y personajes, en los títulos de capítulos ("Sueño de una noche de ver anos") y en los epígrafes, entre otros. 
forma, lo que está escrito puede "desdecirse", contrariarse, olvidarse, esfumarse como en la oralidad, excediendo las "reglas" de lo escrito, ubicándose en su reverso y en lo subterráneo de las palabras. La palabra, de esta forma, está "barroquizada" y dotada de la potencialidad de la explosión de significante a nivel, incluso, del ritmo. Así, lo que es y lo que no es, lo oculto y lo visible, lo alto y lo bajo "embarrados" - los fósiles vivientes -, conviven no como partes dicotómicas, sino como anverso y reverso de una misma moneda: como el reverso del asfalto que pisamos.

La experiencia de su lectura se vuelve una "experiencia de los susurros" que "denota un ruido límite, un ruido imposible" (BARTHES, 2013b, p. 116), pero que Cárdenas ha podido escuchar y emitir.

Podríamos pensar en la imagen del guardacositas o del caminante laliano: un "recolector" de los restos que los incorpora y se vuelven parte del tejido. Villa Fátima y su sonido de bailanta tropical sería un ejemplo que, a nivel general, contribuye al avance del murmullo. Como lectores, recorremos La Paz y su cartografía, no sólo territorial sino también sonora: escuchamos a la oralidad, pero también el murmullo que se recorre en tanto es un avance en el tiempo. Nosotros lo transitamos, hacemos ese recorrido, lo sentimos, nos agitamos pero, lo más importante, no dejamos de escucharlo. De esta forma, el sonido se vuelve un acontecimiento materializado en lo escrito, una sensación que experimentamos y el reverso de la palabra.

\section{Referencias}

BARTHES, R. Lo obvio y lo obtuso: imágenes, gestos, voces. Barcelona: Paidós, 2002.

BARTHES, R. El grano de la voz. Entrevistas 1962-1980. Buenos Aires: Siglo Veintiuno Editores, 2013.

CAMACHO, W. El misterio del estido. La Paz: Gente común, 2009.

CÁRDENAS, A. Periférica Blvd. La Paz: Editorial 3600, 2013.

DE CERTEAU, M. La invención de lo cotidiano. I. Arte de hacer. México DF: Universidad Iberoamericana, 2000.

DELEUZE, G. Conversaciones 1972- 1990. Valencia: Pre-textos, 1996.

DELEUZE, G. y GUATTARI, F. Mil Mesetas. Capitalismo y esquizofrenia. Valencia: Pre- textos, 2004.

LALO, E. Donde. San Juan: Editorial Tal Cual, 2005. 
LALO, E. Los países invisibles. San Juan: Editorial Tal Cual, 2008.

PRADA, A. R. "La opera rock-ocó de Adolfo Cárdenas" en: Escritos críticos. Literatura boliviana contemporánea. La Paz: IEB/ Carrera de Literatura UMSA/Sierpe, 2012.

RIVERA CUSICANQUI, S. Ch’ixinakaxutxiwa. Una reflexión sobre prácticas y discursos descolonizadores. Buenos Aires: Tinta Limón, 2010.

SARDUY, S. El barroco y el neobarroco. Buenos Aires: El cuenco de plata, 2011.

Data de recebimento: $26 / 11 / 2018$

Data de aceite: 28/12/2018 